\title{
Graphene Oxide Applications in Dentistry: Integrative Literature Review
}

\section{Aplicações de Óxido de Grafeno na Odontologia: uma Revisão Integrativa da Literatura}

\author{
André Farias de Oliveira Malta ${ }^{\mathrm{a}}$; Davi Luiz Lage Cortez; $z^{\mathrm{a}}$ Dayse Andrade Romãoa; José Eduardo Candido Holanda \\ Pereira $^{a}$; Marilia Mattar de Amoêdo Campos Velo*b; Tatiana Rita de Lima Nascimento ${ }^{c}$
}

aTiradentes University Center Unit, Maceió, AL, Brazil.

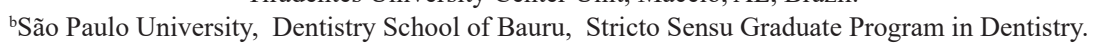

'Federal University of Paraíba, João Pessoa, PB, Brazil.

*E-mail: mariliavelo@yahoo.com.br

Recebido em: 25/03/2019; Aprovado em: 06/05/2019

\begin{abstract}
Graphene and its derivatives, such as graphene oxide, represent the greatest potential materials in terms of biomaterials due to their excellent physical-chemical and biological properties. Thus, the present study has developed an integrative literature review in order to evaluate the capacity of graphene oxide to replace metal biomaterials currently used in Dentistry. For this purpose, LILACS, SciELO and PubMED databases were evaluated, with the following descriptors: graphene, biomaterials and Odontology, adapted for each database used. Firstly, the descriptors were searched separately and, later, the Boolean operator AND was used to define a search strategy. The articles were selected according to the following inclusion criteria: articles in Portuguese, English and Spanish, published and indexed in the databases, in the last ten years, with texts available in full and regarding the topic under study. A total of 14 scientific papers were found and 10 of them were selected for this review. After the critical reading of each article, it was possible to observe that graphene and its derivates present great biocompatibility, excellent mechanical, electrical and thermic properties, high flexibility, low density and a huge potential to be explored in health science. It is also important to highlight its potential application as a coating of metal biomaterials.
\end{abstract}

Keywords: Biocompatible Materials. Materials Testing. Dentistry.

\section{Resumo}

O grafeno e seus derivados, como o óxido de grafeno, representam atualmente o maior potencial em termos de biomateriais, devido às suas excelentes propriedades fisico-químicas e de biocompatibilidade. Assim, o presente estudo teve como premissa conduzir uma revisão integrativa da literatura de modo a verificar a capacidade do óxido de grafeno em substituir os biomateriais metálicos atualmente utilizados na Odontologia. Para isto, foram utilizadas as bases de dados Lilacs, SciELO e Pubmed, com os seguintes descritores: grafeno, biomateriais e Odontologia, adaptados para cada base de dados utilizada. Primeiramente, os descritores foram pesquisados isoladamente e, posteriormente, o operador booleano AND foi utilizado de modo a definir uma estratégia de busca. Os artigos foram selecionados de acordo com os critérios de inclusão: artigos em Português, Inglês e Espanhol, publicados e indexados nas referidas bases de dados, nos últimos dez anos, com texto disponivel na integra e que retratassem a temática em estudo. Foram encontrados um total de 14 artigos cientificos e, dez destes artigos foram selecionados para compor a revisão. A partir da leitura crítica de cada artigo, foi possível observar que o grafeno e seus derivados apresentam uma alta biocompatibilidade, notáveis propriedades mecânicas, elétricas e térmicas, alta flexibilidade, baixa densidade de massa e um enorme potencial a ser explorado para beneficiar a área da saúde. Deve-se, também, destacar sua potencial aplicação como revestimento de materiais metálicos implantáveis.

Palavras-chave: Materiais Biocompativeis. Teste de Materiais. Odontologia.

\section{Introduction}

The biomaterials or biomedical materials have been refined over the years, varying in their origins or chemical compositions and, also, in relation to their effects and spatial conformations ${ }^{1}$. However, one of the major limitations involving the biomaterials concerns the degree of biocompatibility achieved, i.e., the ability of the biomaterial to join the biological tissue without causing any damage ${ }^{2}$. In the case of metallic materials, widely used in Dentistry, it is necessary to emphasize that even the alloys with higher resistance to corrosion, as the pure titanium and its derivatives are prone to corrosion, can induce systemic effects in the patient's body, due to its by-products released by degradation ${ }^{2}$.
More Currently, with the discovery of graphene and its derivatives, due to the high biocompatibility of these materials, they became one of the great promises in terms of biomaterials in the scientific community, with potential applications in Regenerative Medicine, Dentistry and Materials Sciences ${ }^{3}$. Structurally composed by a monolayer of carbon atoms arranged in a hexagonal structure with two-dimensional format, the graphene has outstanding electrical, thermal and mechanical properties ${ }^{4}$. In addition, its molecular structure can be chemically modified, enabling its accession to different molecules, promoting the development of high-performance devices $^{5}$. One of the main advantages of graphene is its high biocompatibility, property of extreme importance for several 
areas, mainly in the area of health, thus allowing different possibilities of applications, and can be used as the carrier of genes, proteins and drugs, the coating material for implants, inducing proliferation and differentiation of stem cells and as inducer of bone regeneration and caries ${ }^{6.7}$.

An experimental study conducted by Suo et al. ${ }^{8}$ examined dental implants of titanium coated with graphene oxide, chitosan and hydroxyapatite, these being used separately and together. The results obtained showed a homogeneous coating, without cracks and with osteo-integration improved in vivo. In addition, the coating of oxide of graphene, chitosan and hydroxyapatite had great interaction with cells in vitro. These findings indicate that the coating of oxide of graphene could have potentially promising applications in the field of implantology.

Still in the area of Dentistry, the osteo-integration of dental implants coated with graphene oxide demonstrates a better biocompatibility, and bacteriostatic action without changing the properties of the material, inhibiting the growth of $S$. mutans when aggregated in adhesives for restores of resin, in the form of nanoplatelets ${ }^{9}$. In addition, graphene proved to be useful in dental whitening procedures, increasing the action of bleaching by facilitating the market penetration of hydrogen peroxide and acting as a catalyst for the action of the hydrogen peroxide, thus reducing the time of treatment, which decreases the aggression to the gums and causing less sensitivity $^{10}$.

Thus, in view of the potential that the graphene represents for Dentistry, the discussion of this material is essential. Thus, the present study had as an objective to carry out an integrative literature review in order to evaluate the capacity of graphene oxide to replace metal biomaterials currently used in Dentistry. By means of the researched literature, a guiding question was raised: what is the capacity of the graphene oxide in solving the problems of biocompatibility of metallic biomaterials used in dentistry?

\section{Development}

\subsection{Methodology}

An integrative literature review includes the analysis of relevant research that provide support for decision making and the improvement of clinical practice, allowing the synthesis of the state of knowledge of a particular subject, in addition to pointing out gaps in knowledge that need to be fulfilled with the conduction of further studies. This research method allows the synthesis of multiple published studies and provides general conclusions regarding a particular area of study ${ }^{11}$. The preparation of the integrative review requires a thorough analysis of the literature through six stages: Select the hypotheses or questions for the review, the definition of the criteria for selection, definition of the characteristics of the original research, data analysis, interpretation of results and presentation of the review. The databases LILACS, SciELO and PubMED were used. The descriptors used for the article were: grafeno, graphene, biomateriais, biomaterials, Odontologia and Odontology, first studied separately and subsequently being united by the Boolean operator AND. The inclusion criteria used for the sample selection were: articles in Portuguese, English and Spanish, published and indexed in the databases, in the last ten years, with texts available in full and regarding the topic under study. Tables 1, 2 and 3 represent the number of articles found in LILACs, and PubMED ScieELO, respectively.

Table 1 - Publications found between the years 2007 and 2018 according to the Lilacs database.

\begin{tabular}{|l|c|c|c|c|}
\hline \multicolumn{1}{|c|}{ Descriptor } & $\begin{array}{c}\text { Total of } \\
\text { publications }\end{array}$ & $\begin{array}{c}\text { Publications } \\
\text { Filtered }\end{array}$ & $\begin{array}{c}\text { After reading the } \\
\text { Title }\end{array}$ & $\begin{array}{c}\text { After reading the } \\
\text { Title }\end{array}$ \\
\hline Graphene & 2 & 2 & 0 & 0 \\
\hline Biomateriales & 1198 & 43 & 12 & 0 \\
\hline Dentistry & 18,387 & 48 & 14 & 0 \\
\hline Grafeno y Biomateriales & 0 & 0 & 0 & 0 \\
\hline Grafeno y Biomateriales & 0 & 0 & 0 & 0 \\
\hline Grafeno y Biomateriales & 402 & 2 & 0 & 0 \\
\hline Grafeno y Biomateriales & 0 & 0 & 0 & 0 \\
\hline
\end{tabular}

Source: Research data.

Table 2 - Publications found between the years 2007 and 2018 according to the Lilacs database

\begin{tabular}{|l|c|c|c|c|}
\hline \multicolumn{1}{|c|}{ Descriptor } & $\begin{array}{c}\text { Total of } \\
\text { publications }\end{array}$ & $\begin{array}{c}\text { Publications } \\
\text { Filtered }\end{array}$ & $\begin{array}{c}\text { After reading the } \\
\text { Title }\end{array}$ & $\begin{array}{c}\text { After reading the } \\
\text { Title }\end{array}$ \\
\hline Graphene & 45 & 30 & 8 & 1 \\
\hline Biomaterials & 165 & 37 & 7 & 0 \\
\hline Odontologia & 3435 & 640 & 6 & 0 \\
\hline Grafeno e Biomateriais & 0 & 0 & 0 & 0 \\
\hline Grafeno y Biomateriales & 0 & 0 & 0 & 0 \\
\hline Biomateriais e Odontologia & 10 & 5 & 0 & 0 \\
\hline Grafeno e Biomateriais e Odontologia & 0 & 0 & 0 & 0 \\
\hline So
\end{tabular}


Table 3 - Publications found between the years 2007 and 2018 according to PUBMED database

\begin{tabular}{|l|c|c|c|c|}
\hline \multicolumn{1}{|c|}{ Descriptor } & $\begin{array}{c}\text { Total of } \\
\text { publications }\end{array}$ & $\begin{array}{c}\text { Publications } \\
\text { Filtered }\end{array}$ & $\begin{array}{c}\text { After reading } \\
\text { the Title }\end{array}$ & $\begin{array}{c}\text { After reading } \\
\text { the Title }\end{array}$ \\
\hline Graphene & 49356 & 149 & 9 & 7 \\
\hline Biomaterials & 170462 & 631 & 1 & 1 \\
\hline Odontology & 8894 & 4 & 0 & 0 \\
\hline Graphene and Biomaterials & 1994 & 62 & 7 & 2 \\
\hline Graphene and Odontology & 3 & 0 & 0 & 0 \\
\hline Graphene and Odontology & 457 & 0 & 0 & 0 \\
\hline Graphene and Biomaterials and Odontology & 0 & 0 & 0 & 0 \\
\hline
\end{tabular}

Source: Research data.

The strategies used for the survey of the articles were adapted to each database, according to the theme of research, having as main tab the guiding question and the inclusion criteria. Information on graphene and its conformation as biomaterial, as well as associated to other biomaterials, with a focus on the use as dental materials were considered as an instrument for data collection .

In the Lilacs database, the descriptors were surveyed in Spanish and English, but no results were found after the union of the descriptors with the Boolean operator AND.
In the SciELO database, the keywords in Portuguese and English were used: graphene, biomaterials and dentistry; biomateriais, odontologia and grafeno. After filtering and the union of descriptors four articles were selected judged as relevant to the research. In the PUBMED database only the descriptors in English were used: graphene, biomaterials and odontology, being considered, after the filter and the union of descriptors using the AND operator, a total of six articles. For better information observed the Table 4.

Table 4 - Characterization of selected articles for the integrative review.

\begin{tabular}{|c|c|c|c|c|}
\hline Title & Authors & Year & Design & Outcome \\
\hline $\begin{array}{l}\text { Carbon nanostructures } \\
\text { (nanotubes, } \\
\text { graphene): Quo Vadis? }\end{array}$ & $\begin{array}{l}\text { Aldo JG, } \\
\text { Zarbin MMO }\end{array}$ & 2013 & $\begin{array}{c}\text { Descriptive } \\
\text { study /Survey }\end{array}$ & $\begin{array}{l}\text { Research shows that the carbon-based nanomaterial reached } \\
\text { a satisfactory level in a matter of production, however, such } \\
\text { progress still needs to be accompanied by areas of public health, } \\
\text { for example. }\end{array}$ \\
\hline $\begin{array}{l}\text { Cytotoxicity of graphene } \\
\text { oxide and graphene oxide } \\
\text { loaded with doxorubicin } \\
\text { on human multiple } \\
\text { myeloma cells. } \\
\end{array}$ & $\begin{array}{l}\text { Wu S, Zhao } \\
\text { X, Zhao } \\
\text { Wang Y, Du } \\
\text { L, Li Y. }\end{array}$ & 2014 & $\begin{array}{l}\text { Experimental } \\
\text { study / } \\
\text { Laboratory }\end{array}$ & $\begin{array}{l}\text { The study proves that the graphene oxide did not induce } \\
\text { apoptosis nor altered the cell cycle, being a highly biocompatible } \\
\text { material with practical applications. }\end{array}$ \\
\hline $\begin{array}{l}\text { Comparison between } \\
\text { nanocomposites made } \\
\text { of polyethylene/ } \\
\text { carbon nanotubes and } \\
\text { polyethylene/nanosheets } \\
\text { of graphene obtained by } \\
\text { in situ polymerization }\end{array}$ & Fim FC et al. & 2014 & $\begin{array}{l}\text { Experimental } \\
\text { study / } \\
\text { Laboratory }\end{array}$ & $\begin{array}{l}\text { The experiment concluded that the differences observed between } \\
\text { the carbon nanocomposites are associated to their morphological } \\
\text { distinctions. }\end{array}$ \\
\hline $\begin{array}{l}\text { Graphene based scaffolds } \\
\text { effects on stem cells } \\
\text { commitment. }\end{array}$ & $\begin{array}{l}\text { Bressan E, et } \\
\text { al. }\end{array}$ & 2014 & $\begin{array}{l}\text { Systematic } \\
\text { review. }\end{array}$ & $\begin{array}{l}\text { The research concludes that the graphene and related materials } \\
\text { are, in addition to highly biocompatible, able to induce human } \\
\text { embryonic stem cells to differentiate into specific lineages, since } \\
\text { periodontal ligament cells to neuronal cells. }\end{array}$ \\
\hline $\begin{array}{l}\text { Assessment of the } \\
\text { surface hardness of } \\
\text { glass ionomer cements, } \\
\text { reinforced with carbon } \\
\text { nanotubes. }\end{array}$ & $\begin{array}{l}\text { Santos, MPR } \\
\text { et al. }\end{array}$ & 2015 & $\begin{array}{c}\text { Case-control } \\
\text { study }\end{array}$ & $\begin{array}{l}\text { The study shows that the glass ionomer cements do not have } \\
\text { good aggregation with the nanotubes of carbon, because they } \\
\text { lose resistance upon being modified in conjunction. }\end{array}$ \\
\hline $\begin{array}{l}\text { Current applications } \\
\text { of graphene oxide in } \\
\text { nanomedicine. }\end{array}$ & $\begin{array}{l}\text { Wu S, An } \\
\text { SS, Hulme J. }\end{array}$ & 2015 & $\begin{array}{l}\text { Integrative } \\
\text { Review }\end{array}$ & $\begin{array}{l}\text { The study concluded that in the future we will have great impact } \\
\text { in several areas of the biomedical environment, provided by the } \\
\text { base of graphene materials and their properties. }\end{array}$ \\
\hline $\begin{array}{l}\text { Enhanced Osteogenesis } \\
\text { by Reduced Graphene } \\
\text { Oxide/Hydroxyapatite } \\
\text { Nanocomposites. }\end{array}$ & Lee JH et al. & 2015 & $\begin{array}{l}\text { Experimental } \\
\text { study / } \\
\text { Laboratory }\end{array}$ & $\begin{array}{l}\text { The results illustrate that the graphene-based nanomaterials can } \\
\text { be exploited to a range of strategies for renewal of bone and } \\
\text { dental tissues, as it has capabilities of osteogenic induction. }\end{array}$ \\
\hline
\end{tabular}




\begin{tabular}{|l|l|l|l|l|}
\hline $\begin{array}{l}\text { Bioactivity of periodontal } \\
\text { ligament stem cells on } \\
\text { sodium titanate coated } \\
\text { with graphene oxide. }\end{array}$ & $\begin{array}{l}\text { Zhou Q, et } \\
\text { al. }\end{array}$ & 2016 & $\begin{array}{l}\text { Experimental } \\
\text { study / } \\
\text { Laboratory }\end{array}$ & $\begin{array}{l}\text { The results of this study suggest that the combination of graphene } \\
\text { oxide of the stem cells of human periodontal ligament promote a } \\
\text { major breakthrough in the area of regenerative dentistry }\end{array}$ \\
\hline $\begin{array}{l}\text { Biological interactions } \\
\text { of carbon-based } \\
\text { nanomaterials: } \\
\begin{array}{l}\text { From coronation to } \\
\text { degradation. }\end{array}\end{array}$ & $\begin{array}{l}\text { Bhattacharya } \\
\text { K, et al. }\end{array}$ & 2016 & $\begin{array}{l}\text { Systematic } \\
\text { review. }\end{array}$ & $\begin{array}{l}\text { The study argues that the basis of carbon nanomaterials are a } \\
\text { great promise in various branches of medicine, being widely } \\
\text { studied in relation to the treatment of cancer, in addition, there } \\
\text { is an emergency use of these materials in regenerative medicine. } \\
\text { The article highlights the importance of studies regarding the } \\
\text { biocompatibility and toxicity of carbon-based materials. }\end{array}$ \\
\hline $\begin{array}{l}\text { Diseño nanotecnológico } \\
\text { de superficies } \\
\text { con propiedades } \\
\text { antibacterianas: el } \\
\text { grafeno }\end{array}$ & $\begin{array}{l}\text { P. de la Peña } \\
\text { Benítez, } \\
\text { A. García- } \\
\text { Santos. }\end{array}$ & 2016 & $\begin{array}{l}\text { Experimental } \\
\text { study / } \\
\text { Laboratory }\end{array}$ & $\begin{array}{l}\text { The study reports that the graphene has incomparable properties, } \\
\text { generating several possibilities for practical application, } \\
\text { possessing antibacterial activity, promoting promising finish. }\end{array}$ \\
\hline $\begin{array}{l}\text { Suspended graphene } \\
\text { oxide nanoparticle for } \\
\text { accelerated multilayer } \\
\text { osteoblast attachment }\end{array}$ & $\begin{array}{l}\text { Foroutan T, } \\
\text { et al. }\end{array}$ & 2018 & $\begin{array}{l}\text { Experimental } \\
\text { study / } \\
\text { Laboratory }\end{array}$ & $\begin{array}{l}\text { The effects of toxicity of graphene oxide (GO) in cancer cell } \\
\text { line were examined. The connection and expression of genes of } \\
\text { osteoblastic cells were evaluated, concluding that the effect of } \\
\text { GO toxicity are dose-dependent. }\end{array}$ \\
\hline
\end{tabular}

Source: Research data.

\subsection{Discussion}

This study contributes to improve the vision of dental surgeons and researchers about this material that can bring numerous benefits to the area of health. Graphene is a complex structure that has been studied for more than 50 years; however, for a long time the researchers considered impossible to obtain graphene in its free form. However, in 2004, this material was isolated for the first time at the University of Manchester (England), today being the first dimensional isolated stable crystal. After this phase, numerous studies have been conducted to obtain its best form of use, especially in the development of nanotubes, which were obtained with success over the years. However, until the present day, the toxicity of the carbon-based materials have not been fully elucidated, and it is also due to the short time of discovery of these materials, which also deal with limitations of storage contact and discard ${ }^{12}$.

Zarbin and Oliveira ${ }^{12}$, observed that the areas of nanoscience and nanotechnology have grown significantly, because, through changes in the size and format of atoms, new materials emerged, thus enabling the development of innovative products. Figuring among the most significant of these products, are the carbon nanotubes and graphene.

Since their discovery in 1991, the carbon nanotubes have been the focus of considerable research and widely used in Dentistry. Due to their remarkable mechanical, electrical and thermal properties, their high flexibility and low mass density, the carbon nanotubes become potential candidates for the development of polymeric composites ${ }^{13}$. In the experiment of Fim et al. ${ }^{13}$, the nanocomposites made of polyethylene/carbon nanotubes were synthesized by in situ polymerization to be compared with polyethylene nanocomposites/nanosheets of graphene, obtained under the same conditions. It was possible to observe that graphene is similar to copper as conductor of electricity, and as conductor of heat, surpasses all other materials known to date. It is considered one of the toughest materials that exists, and even being resistant, graphene can be lengthened by up to $25 \%$ of its length, property highly desirable for the development of dental materials. Another great advantage of this material on the carbon nanotubes is that graphene can be obtained from graphite by methods of exfoliation, either mechanical or chemical, while the carbon nanotubes are difficult to be obtained. Regarding the mechanical properties in dynamic mode, what can be said is that the carbon nanotubes had greater interaction with the polymer than those of graphene, probably due to the morphology of nanoload, because one is formed of nanotubes and the other of nanosheets ${ }^{13}$.

Regarding the biocompatibility, Wu et al. ${ }^{6}$ pointed out that the graphene oxide did not induce apoptosis in the studied cells, showing to be a highly biocompatible nanomaterial with several practical applications. Therefore, graphene provides a new type of coating material that confers the pro-osteo differentiation ability in implants and supportive materials, through surface modifications. The coating of implantable materials with graphene proved to be a safe and effective method to obtain osteoblasts from mesenchymal stem cells and pre-osteoblasts. Both (graphene and graphene oxide) were characterized as preparatory to chemicals, proteins and growth factors in their surface to promote cellular differentiation?

According to $\mathrm{Wu}$ et al. ${ }^{14}$, the sheets of graphene and graphene oxide are easily synthesized by the method Hummers or its variants. In addition, the graphene oxide contains many hydrophilic groups on the ends of its molecules or baseline plans, thus, leaves of small size and lower concentrations should be much more biocompatible. These properties make the graphene oxide extremely attractive to a wide range of researchers with new applications in the fields of transport of drugs, parasitology, tissue engineering, anti-bacterial, therapy of cancer, images of sensors and diagnostics. 
According to Penã and García-Santos ${ }^{15}$, it is possible to affirm that graphene is a biocompatible material and, in turn, does not allow the bacterial growth on its surface, thus becoming a material with an important potential for development in areas that are susceptible to infections, however the toxicity of graphene oxide is dose-dependent ${ }^{16}$. Thus, a great number of current publications have analyzed the graphene with bactericidal purposes; however, each method of obtaining graphene sheets, each derivative from this material gives different properties to the result, so it is important to systematize and classify each one of these materials, prior to obtaining applications in clinical practice ${ }^{15}$.

However, it is important to emphasize that the issue of safety and toxicity in relation to graphene oxide and its potential benefits to the health of society are still far from being elucidated. Many previous investigations showed that the graphene oxide and its hybrid structures induce low cellular toxicity, but studies are conflicting. The origin of this debate can be due to subtle epigenetic processes associated with aberrant gene expression ${ }^{6}$.

Despite this, due to its physical-chemical properties unique, graphene and its derivatives have been considered very promising candidates in the biomedical area, being used as nanocarriers of genes and drugs, biosensors, cellulography and phototherapy of cancer ${ }^{7}$. The results of this study prove that the graphene oxide plays an important role in promoting the differentiation of stem cells into osteoblasts. In addition, stem cells from human periodontal ligament, being associated with graphene oxide showed a greater density than those associated with other materials and substrate culture proliferated at a higher pace. Such effect caused in stem cells from periodontal ligament shows that the graphene oxide allows more pluripotent cells grow, facilitating the regeneration of bone tissue.

The morphology and the results of proliferation observed in cells indicate which substrates coated with the graphene oxide are biocompatible. The substrates associated with titanium alloy and graphene oxide promotes adhesion and cell proliferation, which can be attributed to the superficial alteration of graphene oxide. According to Zhou et al. ${ }^{7}$, the graphene oxide can not only affect the format, adhesion, migration and proliferation, but also determine the behavior of stem cells in different lineages. However, the exact reason by which the substrate associated with titanium alloy and graphene oxide promotes adhesion, proliferation and cellular differentiation remains unknown?

Future studies should focus on how to use the graphene oxide as an implantable, biocompatible material and associated with the transport of therapeutic proteins for applications related to regenerative medicine, especially for the success of dental implants, since these implants composed of a titanium alloy and graphene oxide can be combined to therapeutic proteins carriers to enhance the integration of the implant with the bone tissue of the implanted site?

In recent years, the applications of graphene grew exponentially. The graphene has a great potential for development as a new tool in the fight against infections acquired in hospitals, applied to the projects that utilize a new antibacterial surface and materials used in sensitive locations for patients and users ${ }^{15}$. Bhattacharya et al. ${ }^{16}$, showed that graphene is a material with many promising areas of application as a result of its large surface area and the possibility of easy to use. In the experimental studies of Suo et al. ${ }^{8}$ about the use of graphene in Dentistry, the authors found that the graphene could have potentially promising applications in the field of implantology, since they obtained a homogeneous coating, without cracks and with osteo-integration improved in vivo.

In corroboration with the above data, it was described improvement of biocompatibility and osteo-integration of dental implants coated with graphene oxide and pointed out that this material had bacteriostatic action, inhibiting the growth of $S$. mutans when aggregated in adhesives for restores of resin, in the form of nanosheets ${ }^{9}$. In contrast, in this same research ${ }^{9}$, the authors warned about the limitation still present during the production of graphene composites. Since the studies about using small-scale productions, have no concrete data that argue that their production on a large scale is homogeneous and without defects.

In general, it is concluded through this integrative review of literature that many studies are still necessary regarding the cytotoxicity of graphene. In addition, its indication in dentistry has not been well established, since the studies are still in the initial and laboratory phase. However, promising results of studies already conducted show that graphene is, in fact, the biomaterial until today discovered with greater potential for application.

\section{Conclusion}

The graphene and its derivatives were identified as materials of High biocompatibility, with numerous properties extremely significant to the area of health, such as: ability to induce bone and dental regeneration, as well as the differentiation and proliferation of stem cells, bactericidal properties, allow the carriage of drugs, have high electrical and thermal conductivity and application as a coating of implantable materials such as titanium used for dental implants. It is highlighted just that the data about its toxicity have not been completely elucidated and future investigations are still needed.

\section{References}

1. Hench LL, Splinter RJ, Allen WC, Greenlee TK. Bonding mechanisms at the interface of ceramic prosthetic materials. J Biomed Mater Res 1971;5:117-41. doi: 10.1002/ jbm.820050611

2. Sinhoreti MA, Vitti RP, Correr-Sobrinho L. Biomateriais na Odontologia: panorama atual e perspectivas futuras. Rev 
Assoc Paul Cir Dent 2013;67(3):178-86.

3. Chung C, Kim YK, Shin D, Ryoo SR, Hong BH. "Biomedical applications of graphene and graphene oxide". Accounts Chem Res 2013;46(10):2211-24. doi: 10.1021/ar300159f

4. Novoselov KS, Geim AK, Morozov SV, Jiang D, Zhang $\mathrm{Y}$, Dubonos SV, et al. Electric field effect in atomically thin carbon films science. Sci Rep 2004;306(5696):666-9. doi: 10.1126/science. 110289 .

5. Bressan E, Ferroni L, Gardin C, Sbricoli L, Gobbato L, Ludovichetti FS, et al. Graphene based scaffolds effects on stem cells commitment. J Translat Med 2014;12:296. doi: 10.1186/s12967-014-0296-9

6. Wu S, Zhao X, Cui Z, Zhao C, Wang Y, Du L, Li Y. Cytotoxicity of graphene oxide and graphene oxide loaded with doxorubicin on human multiple myeloma cells. Int J Nanomedicine. 2014;14(9):1413-21. doi: 10.2147/IJN. S57946

7. Zhou Q, Yang P, Li X, Liu H, Ge S. Bioactivity of periodontal ligament stem cells on sodium titanate coated with graphene oxide. Sci Rep 2016;14(6):19343. doi: 10.1038/srep19343

8. Suo L, Jiang N, Wang Y, Wang P, Chen J, Pei X, Wang J, Wan Q. The enhancement of osseointegration using a graphene oxide/chitosan/hydroxyapatite composite coating on titanium fabricated by electrophoretic deposition. J Biomed Mater Res B Appl Biomater 2019;107B:635-45. doi: 10.1002/ jbm.b.34156.

9. Guazzo R, Gardin C, Bellin G, Sbricoli L, Ferroni L, Ludovichetti FS, et al. Graphene-based nanomaterials for tissue engineering in the dental field. Nanomaterials (Basel) 2018;8(5):349. doi: 10.3390/nano8050349.

10. Su IH, Lee CF, Su YP, Wang LH. Evaluating a cobalt- tetraphenylporphyrin complex, functionalized with a reduced graphene oxide nanocomposite, for improved tooth whitening. J Esthet Restor Dent 2016;285:321-9. doi: $10.1111 /$ jerd. 12240

11. Mendes KDS, Silveira RCCP, GalvãoCM. Integrativeliterature review: a research method to incorporate evidence in health care and nursing. Texto Contexto Enferm 2008;17(4):758-64. doi: $10.1590 / \mathrm{S} 0104-07072008000400018$

12. Zarbin AJG, Oliveira MM. Nanoestruturas de carbono (nanotubos, grafeno): Quo Vadis?. Quím Nova 2013;36(10):1533-9. doi: 10.1590/S010040422013001000009

13. Wu SY, An SS, Hulme J. Current applications of graphene oxide in nanomedicine. Int J Nanomedicine 2015;10:9-24. doi: $10.2147 /$ IJN.S88285

14. Wu SY, An SS, Hulme J. Current applications of graphene oxide in nanomedicine. Int J Nanomed 2015;10:9-24. doi: $10.2147 / \mathrm{IJN} . \mathrm{S} 88285$.

15. Penã Benítez P, García-Santos A. Diseño nanotecnológico de superficies con propiedades antibacterianas: el grafeno. Rev Ing Constr 2016;31(3). doi:10.4067/S071850732016000300006

16. Foroutan T, Nazemi N, Tavana M, Kassaee MZ, Motamedi E, Soieshargh $\mathrm{S}$ et al. Suspended graphene oxide nanoparticle for accelerated multilayer osteoblast attachment. J Biomed Mater Res A 2018;106(1):293-303. doi:10.1002/jbm.a.36231.

17. Bhattacharya K, Mukherjee SP, Gallud A, Burkert SC, Bistarelli S, Bellucci $\mathrm{S}$ et al. Biological interactions of carbon-based nanomaterials: From coronation to degradation. Nanomedicine 2016;1(2):333-51. doi: 10.1016/j. nano.2015.11.011 